\title{
COMPARATIVE STUDY OF DARK BEER BEFORE AND AFTER FREEZE DRYING REHYDRATION CYCLE
}

\author{
Ingmārs Cinkmanis", Guntis Gailums, and Sanita Vucāne \\ Faculty of Food Technology, Latvia University of Life Sciences and Technologies, \\ 2 Lielā Str., Jelgava, LV-3001, LATVIA \\ \# Corresponding author, ingmars.cinkmanis@llu.lv
}

Communicated by Andris Zicmanis

The aim of the study was to compare dark beer before and after a freeze drying rehydration cycle. The $\mathrm{pH}$, colour, and concentrations of extract, organic acids, and phenolic compounds were determined. Dark beer before and after freeze drying was analysed using standard brewing analysis methods of the Mitteleuropäische Brautechnische Analysenkommision (MEBAK) and two types of chromatography: high-performance liquid chromatography (HPLC) and gas chromatography mass spectrometry (GC/MS). Increase of $\mathrm{pH}$ was not observed in dark beer after freeze drying. Dissolved powdered beer in deionised water was clear, dark brown, without sediments, and reproduced the original commercially available dark beer, with original extract substance content $8.88 \%$. Concentrations of the following organic acids were determined: oxalic, tartaric, quinic, malic, ascorbic, lactic, acetic, citric, fumaric, and succinic. Volatile compounds by GC/MS analysis were isolated from dark beer before and after freeze drying.

Key words: dark beer, rehydration, freeze drying, extract substances.

\section{INTRODUCTION}

Beverage production is a significant component of the food industry in almost all countries worldwide. Beer contains higher concentrations of aliphatic and aromatic spirits, carboxylic acid esters, carboxylic acids, proteins, and sulphur compounds, and provides four basic tastes: salty, bitter, sour, and sweet. In addition, beer can have tastes like dry fruit, boiled vegetables, caramel, apple, banana, cloves, paper, metal, and mould. In the course of time the quality and content of beer change along with the development of production technologies and science. Traditionally beer is clear, with a pleasant taste of hops and consistent foam at the top. The leading breweries produce not only classical beer, but also offer new kinds of beer in order to attract new consumers. Therefore, new unconventional beer varieties differing significantly from a standard beer are being created (Cinkmanis, 2014). In recent years, a range of beers has been diversified by beer-based mixed drinks made by mixing beer with various lemonades to obtain non-traditional beer drinks.

Traditionally, beverage production is in liquid form, but one of the methods for production of new types of beer is in powdered form. The powdered form of beer can increase its shelf life, as dehydration inhibits microbial growth and decreases degradative reactions, resulting in enhanced stability (Marques et al., 2006). One of the used methods is freeze drying, which allows to make products with high quality, acceptable colour, texture and flavous (Hammami and René, 1997; Gio et al., 2000; Khalloufi and Ratti, 2003).

Beer can contain various phenolic compounds with different chemical structures: phenolic acids, flavonoids, stilbenes, and lignans. These compounds have anti-inflammatory, antibacterial, and antiviral functions, and their effectiveness depends on their stability in food processing and storage (Fang and Bhandari, 2010). Freeze drying can cause an increase of phenolic compound concentration, higher sample porosity and improved extraction efficiency of phenolic compounds from plants. Freeze drying is one of the most appropriate methods to ensure microbial safety and to maintain the physiological properties of products without changes of phenolic compound concentrations in plants (Wojdyloetal, 2009; Moreover and Wuetal, 2010). Decapsulation by freeze drying can be used for protection of the nutraceuticals by preventing oxidation, reducing losses of volatile substances, making handling easier, facilitating or making more difficult the premature interaction with other ingredients, and regulating food bioactive content during industrialisation processes (Munin and Edwards-Levy, 2011; Deyse et al., 2013).

The aim of the study was to compare dark beer before and after a freeze drying rehydration cycle. 


\section{MATERIALS AND METHODS}

The study was carried out at the Department of Chemistry, Faculty of Food Technology, at the Latvia University of Agriculture. The object of the research was Latvian commercially available dark beer.

Freeze drying process. Samples were freeze dried using a Christ Freeze Dryer Alpha 1-2 LD plus (Germany) at -57 ${ }^{\circ} \mathrm{C}$ for 74.24 minutes. Dark beer reproduction with $8.88 \%$ extract from freeze drying powder was prepared by rehydration of $4.44 \mathrm{~g}$ powdered beer dissolved into $45.56 \mathrm{~g}$ deionised water, continuously mixing for 20 minutes.

Determination of $\mathbf{p H}$. The $\mathrm{pH}$ of beer samples was measured using potentiometric method with a WTW $\mathrm{pH}$ ( $\mathrm{pH} 538$ ) meter (MEBAK, 2013). A Sen Tix electrode 97T was used.

Determination of colour. The colour of beer was determined by spectrophotometric method. The determination of beer colour was based on the absorption of light measured at wave length $430 \mathrm{~nm}$ (MEBAK, 2013).

Determination of extract content. Extract content of dark beer was determined before and after freeze drying.

Determination of organic acid concentrations. Concentration of organic acids was determined with a high performance liquid chromatography (HPLC) (Schimadzu LC-20 Prominence, Shimadzu USA Manufacturing Inc, Canby, USA), detector DAD SPD-M20A, Solvent Delivery Unit LC-20AD, Column Oven CTO-20A, Autosampler SIL-20A, System Controller CBM-20A and data system LCsolution software.

The following were weighed in a $50 \mathrm{ml}$ volumetric flask with narrow neck: $0.0500 \pm 0.0001 \mathrm{~g}$ oxalic, $0.1000 \pm$ $0.0001 \mathrm{~g}, 0.1000 \pm 0.0001 \mathrm{~g}$ tartaric, $0.1000 \pm 0.0001 \mathrm{~g}$ quinic, $0.1000 \pm 0.0001 \mathrm{~g}$ malic, $0.0500 \pm 0.0001 \mathrm{~g}$ ascorbic, $0.15 \mathrm{ml}$ lactic $\left(1.249 \mathrm{~kg} \cdot \mathrm{m}^{-3}\right), 0.15 \mathrm{ml}$ acetic $(1.049$ $\left.\mathrm{kg} \cdot \mathrm{m}^{-3}\right), 0.1000 \pm 0.0001 \mathrm{~g}$ citric, $0.0205 \pm 0.0001 \mathrm{~g}$ fumaric and $0.2000 \pm 0.0001 \mathrm{~g}$ succinic acids Deionised water was added till mark and mixed.

Parameters of chromatography were: analytical column PerkinElmer C18, $4.6 \mathrm{~mm} \times 250 \mathrm{~mm}, 5 \mu \mathrm{m}$ and temperature of column $+35^{\circ} \mathrm{C}$ and separation of organic acids at wavelength at $210 \mathrm{~nm}$. Injection volume of samples was 10 $\mu 1$. The mobile phase was A (acetonitrile): B $0.05 \mathrm{M}$ $\mathrm{KH}_{2} \mathrm{PO}_{4}$ (1:99) in gradient conditions. Start flow rate was
$1.25 \mathrm{ml} \cdot \mathrm{min}^{-1}$. Each measurement was carried out several times and then the average was calculated.

The calibration chromatogram for organic acids is shown in Figure 1.

Determination of phenolic compound concentrations. Concentrations of phenolic compounds were determined with a High Performance Liquid Chromatography (HPLC) (Schimadzu LC-20 Prominence, Shimadzu USA Manufacturing Inc, Canby, USA), detector DAD SPD-M20A, Solvent Delivery Unit LC-20AD, Column Oven CTO-20A, Autosampler SIL-20A, System Controller CBM-20A and data system LCsolution software.

Preparation of the calibration solution was as follows: weight in $100 \mathrm{ml}$ volumetric flask with narrow neck $6.8 \pm$ $0.1 \mathrm{mg}$ gallic acid, $7.4 \pm 0.1 \mathrm{mg}$ 3.5-dihydroxybenzoic acid, $11.4 \pm 0.1 \mathrm{mg}$ 3.4-dihydroxybenzoic acid, $12.0 \pm 0.1 \mathrm{mg}$ catechin, $12.8 \pm 0.1 \mathrm{mg}$ 4-hydroxybenzoic acid, $13.1 \pm 0.1$ $\mathrm{mg}$ chlorogenic acid, $12.1 \pm 0.1 \mathrm{mg}$ homovanillic acid, 14.5 $\pm 0.1 \mathrm{mg}$ vanillic acid, $13.8 \pm 0.1 \mathrm{mg}$ caffeic acid, $16.0 \pm$ $0.1 \mathrm{mg}$ epicatechin, $18.8 \pm 0.1 \mathrm{mg}$ syringic acid, $9.8 \pm 0.1$ $\mathrm{mg}$ vanillin, $12.1 \pm 0.1 \mathrm{mg}$ p-coumaric acid, $88.1 \pm 0.1 \mathrm{mg}$ sinapinic acid, $9.2 \pm 0.1 \mathrm{mg}$ ferulic acid, $11.2 \pm 0.1 \mathrm{mg} 2-$ hydroxycinnamic acid, $6.1 \pm 0.1 \mathrm{mg}$ rutin, $10.3 \pm 0.1 \mathrm{mg}$ trans-4-hydroxycinnamic acid, $4.3 \pm 0.1 \mathrm{mg}$ quercetin, $9.1 \pm$ $0.1 \mathrm{mg}$ luteolin and $9.6 \pm 0.1 \mathrm{mg}$ kaempherol. HPLC grade CHROMASOLV ${ }^{\circledR}$ methanol was added till mark and mixed.

Parameters of chromatography were: analytical column PerkinElmer C18, $4.6 \mathrm{~mm} \times 250 \mathrm{~mm}, 5 \mu \mathrm{m}$ and temperature of column $+30{ }^{\circ} \mathrm{C}$, and separation of polyphenols at wavelength $278 \mathrm{~nm}$. Injection volume of samples was 100 $\mu \mathrm{L}$. Mobile phase was: A (deionized water), B (HPLC grade CHROMASOLV ${ }^{\circledR}$ methanol) and $\mathrm{C}$ (Acetic acid solution for HPLC) in the gradient conditions. Start flow rate was 1.0 $\mathrm{ml} \cdot \mathrm{min}^{-1}$.

Gradient conditions were: start B $(0 \mathrm{ml})$ : C (2.5 ml); 2 min. $\mathrm{B}(15 \mathrm{ml}): \mathrm{C}(2.4 \mathrm{ml}) ; 12 \mathrm{~min} . \mathrm{B}(18 \mathrm{ml}): \mathrm{C}(2.2 \mathrm{ml})$, flow rate $=0.8 \mathrm{ml} \cdot \mathrm{min}^{-1} ; 20 \mathrm{~min} . \mathrm{B}(20 \mathrm{ml}): \mathrm{C}(1.8 \mathrm{ml})$ flow rate $=0.6 \mathrm{ml} \cdot \mathrm{min}^{-1} ; 25 \mathrm{~min}$., flow rate $=0.5 \mathrm{ml} \cdot \mathrm{min}^{-1} ; 30$ min. $\mathrm{B}(25): \mathrm{C}(1.6 \mathrm{ml}) ; 35 \mathrm{~min}$, flow rate $=0.4 \mathrm{ml} \cdot \mathrm{min}^{-1}$; $40 \mathrm{~min} . \mathrm{B}(30 \mathrm{ml}): \mathrm{C}(1.4 \mathrm{~mL})$; $45 \mathrm{~min}$., flow rate $=0.8 \mathrm{ml}$. $\min ^{-1}$; 50 min. B $(45 \mathrm{ml}): \mathrm{C}(1 \mathrm{ml})$, flow rate $=0.7 \mathrm{ml}$. $\min ^{-1} ; 55 \mathrm{~min} . \mathrm{B}(55 \mathrm{ml}): \mathrm{C}(0.9 \mathrm{ml})$, flow rate $=0.8 \mathrm{ml}$. $\min ^{-1} ; 65 \mathrm{~min} . \mathrm{B}(85 \mathrm{ml}): \mathrm{C}(0.6 \mathrm{ml})$, flow rate $=0.85 \mathrm{ml}$. $\min ^{-1} ; 70 \mathrm{~min} . \mathrm{B}(100 \mathrm{ml}): \mathrm{C}(0 \mathrm{ml})$, flow rate $=1.0 \mathrm{ml}$. $\min ^{-1} ; 73 \mathrm{~min}$. B (0 ml) : C (2.5 ml); $78 \mathrm{~min}$; STOP.

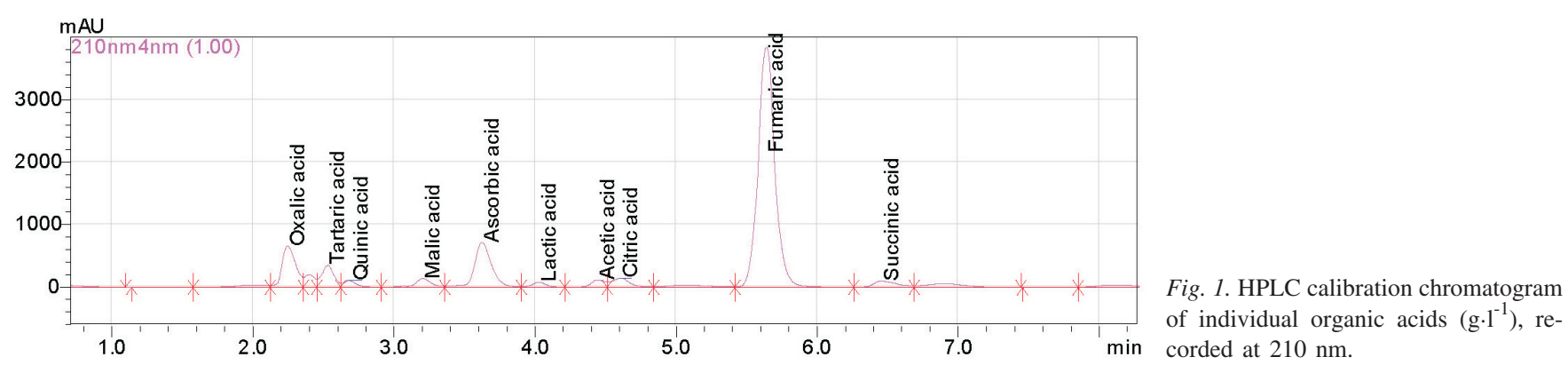




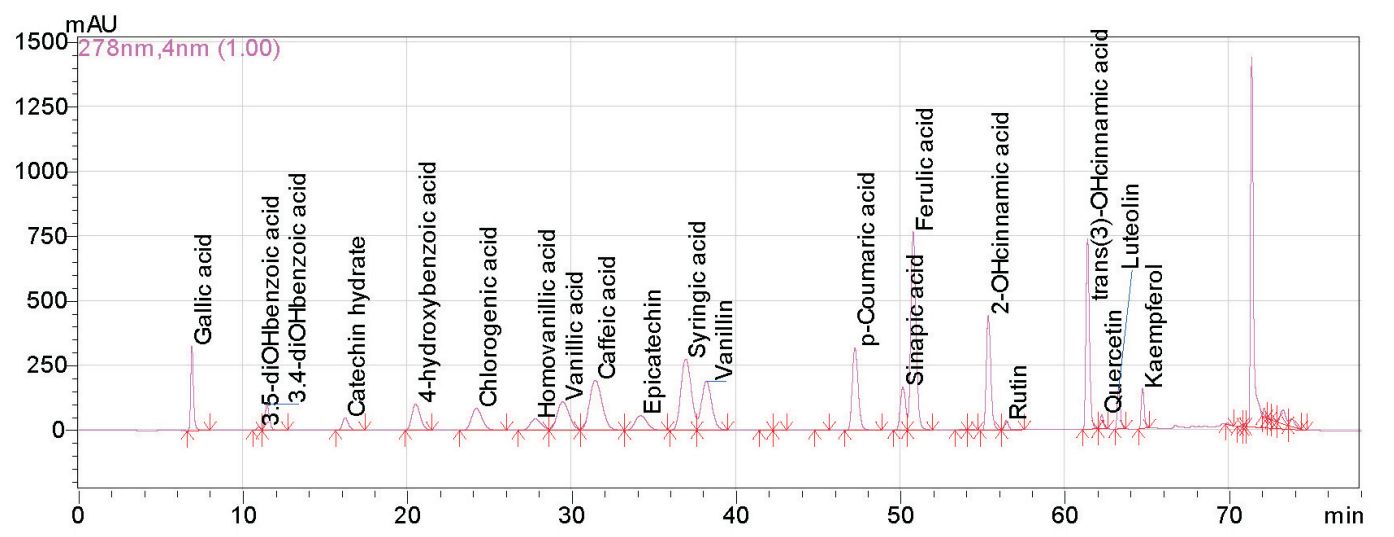

Fig. 2. HPLC calibration chromatogram of individual phenols $\left(\mathrm{mg} \cdot 1^{-1}\right)$, recorded at 278 $\mathrm{nm}$.

The calibration chromatogram of phenols is shown in Figure 2 .

Determination of volatile (aroma) compounds. Concentrations of volatile compounds were determined using a gas chromatography mass spectrometer (GC/MS) Perkin Elmer Clarus 500 according to the Sabovics modified method (Sabovics et al., 2010; 2013). SPME fibre coated with a thin bipolar polymer film $(85 \mu \mathrm{m})$ - Carboxen/Polydimethylsiloxane (CAR/PDMS) (Supelco, Inc., USA) was used. $5.00 \pm 0.05 \mathrm{~g}$ of samples were weighed into $20 \mathrm{ml}$ glass vials, covered with a rubber gasket and sealed with a cork and heated for 30 minutes at $+40{ }^{\circ} \mathrm{C}$ to excrete volatile compounds above the liquid phase. Then a CAR/PDMS fibre was inserted into the vial through the rubber gasket and held above the sample for 30 minutes at $+40{ }^{\circ} \mathrm{C}$ temperature. The samples were injected into an Elite-Wax (PerkinElmer, Inc., USA) capillary column $(60 \mathrm{~m} \times 0.25$ $\mathrm{mm}$ i.d. polyethylene glycol coating thickness $0.25 \mu \mathrm{m})$ with the following parameters: initial temperature $+40{ }^{\circ} \mathrm{C}$, held for $7 \mathrm{~min}$, then ramped from $+40{ }^{\circ} \mathrm{C}$ to $+160{ }^{\circ} \mathrm{C}$ at a rate of $6{ }^{\circ} \mathrm{C} \min ^{-1}$ and from $+160{ }^{\circ} \mathrm{C}$ to $+210{ }^{\circ} \mathrm{C}$ at a rate of $10{ }^{\circ} \mathrm{C}$ min $^{-1}$ then held for $15 \mathrm{~min}$ at $+210{ }^{\circ} \mathrm{C}$. Total run time was $47 \mathrm{~min}$, electron impact ionisation mode $70 \mathrm{eV}$, ion source and inlet line temperature was set to $+250{ }^{\circ} \mathrm{C}$. Injections were performed in split mode $(2: 1)$ at a constant flow of Helium gas of $1 \mathrm{ml} \cdot \mathrm{min}^{-1}$ and full scan mode $-\mathrm{m} / \mathrm{z}$ 40-300. Compounds were identified in mass spectral library Nist98 and measured as peak area units (PAU).

\section{RESULTS}

pH. Change of $\mathrm{pH}$ changes due to freeze drying was not observed in dark beer: $\mathrm{pH}$ before was $4.80 \pm 0.02$ and after $4.97 \pm 0.02$.

Extract content and colour. After 20 minutes of rehydration of powdered beer in deionized water, clear, dark brown beer without sediments was obtained, which reproduced the original commercially available dark beer, with original extract content $8.88 \%$. The extract content was estimated before and after freeze drying. The colour of the beer before freeze drying and after rehydration of the powder was 48.9 EBC.

Organic acid concentration. The concentrations of organic acids (oxalic, tartaric, quinic, malic, ascorbic, lactic, acetic, citric, fumaric, and succinic acid in original dark beer and powder beer were compared (Fig. 3). The HPLC chromatogram of organic acids is showed in Figure 4.

The dominant acids in dark beer before freeze drying were citric $\left(4.47 \mathrm{~g} \cdot 1^{-1}\right)$ and acetic $\left(3.04 \mathrm{~g} \cdot \mathrm{l}^{-1}\right)$ acids, but after freeze drying the concentrations of these acids decreased $1.29 \mathrm{~g} \cdot \mathrm{l}^{-1}$ and $0.37 \mathrm{~g} \cdot \mathrm{l}^{-1}$. Low concentrations were observed for fumaric $\left(0.01 \mathrm{~g} \cdot \mathrm{l}^{-1}\right)$ and ascorbic (from 0.07 to 0.03 $\mathrm{g} \cdot \mathrm{l}^{-1}$ ) acids. Concentrations of most organic acids decrease during freeze drying process, increase of concentrations was observed only for quinic acid (from $0.78 \mathrm{~g} \cdot \mathrm{l}^{-1}$ to $0.82 \mathrm{~g} \cdot \mathrm{l}^{-1}$ ).

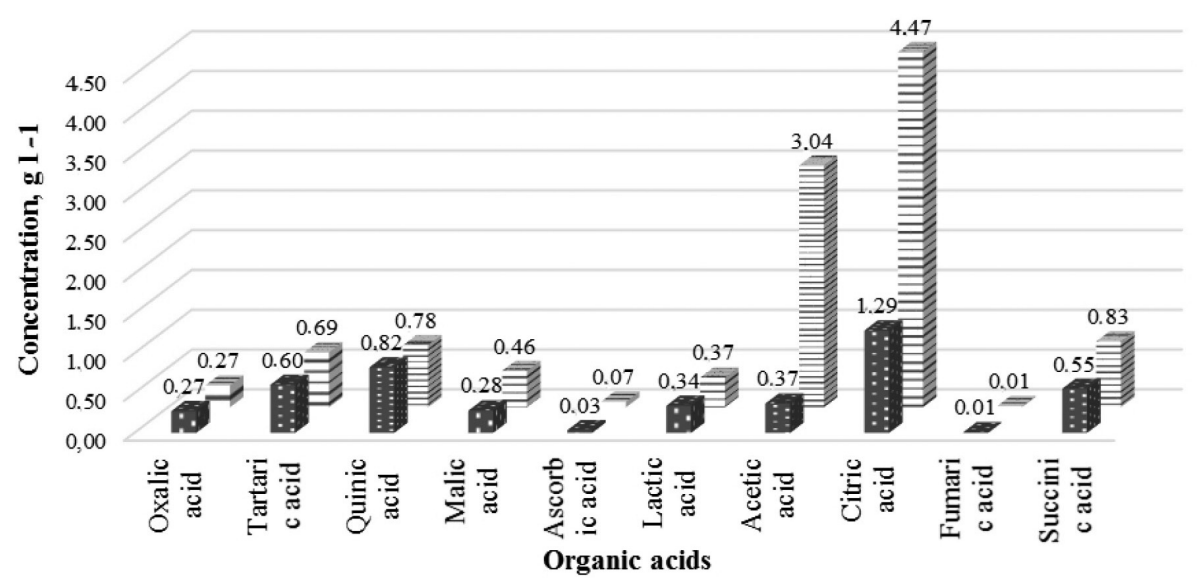

After freeze drying = Before freeze drying

Fig. 3. Content of organic acids before and after freeze drying determined with HPLC, $\mathrm{g} \cdot 1^{-1}$. 


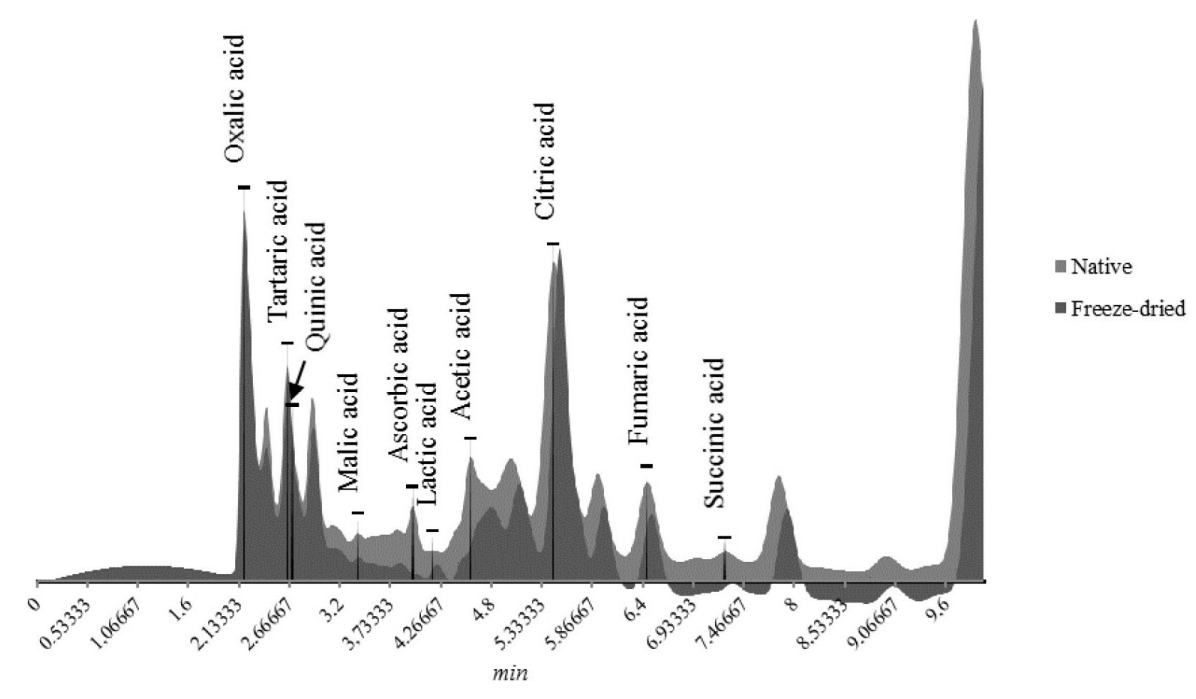

Fig. 4. Detection time (min.) of organic acids HPLC chromatogram in dark beer before and after freeze drying, recorded at $210 \mathrm{~nm}$.
Volatile (aroma) compounds. Eleven volatile compounds were isolated by GC/MS analysis from dark beer before and after freeze drying. Total sum of peak area of the volatile compounds of dark beer was $281.16 \times 10^{6}$ PAU before drying and $106.26 \times 10^{6}$ PAU after drying, which was $62 \%$ lower than for fresh beer (Table 1).

The highest value of peak area in dark beer before drying was observed for the esters isoamyl acetate $\left(87.61 \times 10^{6}\right.$ PAU) and ethyl hexanoate $\left(85.05 \times 10^{6}\right.$ PAU), which provide banana, fruity, green, pineapple and sweet aromas; but after freeze drying the values were about 79.2 to $83.4 \%$ lower. The third and fourth highest peak area values were for ester ethyl octanoate $\left(25.58 \times 10^{6} \mathrm{PAU}\right)$ and spirit 3methylbutan-1-ol $\left(23.53 \times 10^{6} \mathrm{PAU}\right)$, which provide fruit, fat, whiskey, malt, burnt aromas; the values after freeze drying fell to about 50.9 to $13.0 \%$ lower.

The lowest value of peak area in dark beer before drying was for ester ethyl decanoate $\left(2.35 \times 10^{6} \mathrm{PAU}\right.$, after drying $\left.3.47 \times 10^{6} \mathrm{PAU}\right)$, which gives a grape aroma, and saturated fatty acid decanoic acid $\left(1.73 \times 10^{6}\right.$ PAU, after drying $\left.1.30 \times 10^{6} \mathrm{PAU}\right)$ with a rancid, fat aroma.

All of the concentrations of volatile compounds decreased after freeze drying, except for ethyl decanoate, the concentration of which increased up to $47.65 \%$, from $2.35 \pm$ $0.21 \times 10^{6}$ PAU to $3.47 \times 10^{6}$ PAU.

Benzaldehyde was lost in the freeze drying process, but acetic acid appeared after freeze drying.

Determination of phenolic compounds. The highest concentration of phenolic compounds was for catechin before and after freeze drying of dark beer samples: $47.83 \mathrm{mg} \cdot 100$ $\mathrm{ml}^{-1}$ and $48.61 \mathrm{mg} \cdot 100 \mathrm{ml}^{-1}$, respectively. The next highest concentrations were for rutin and 3.5-diOHbenzoic acid (Fig. 5).

Concentrations of twelve of twenty phenolic compounds increased after freeze drying (gallic acid, 3.5-diOHbenzoic acid, 3.4-diOHbenzoic acid, 4-hydroxybenzoic acid, chlorogenic acid, homovanillic acid, vanillic acid, caffeic acid,
Table 1

VOLATILE COMPOUNDS (PAU $\times 10^{6}$ ) IN DARK BEER BEFORE AND AFTER FREEZE DRYING

\begin{tabular}{|c|c|c|c|}
\hline $\begin{array}{c}\text { Volatile } \\
\text { compounds }\end{array}$ & $\begin{array}{c}\text { Odour } \\
\text { descriptors }\end{array}$ & $\begin{array}{c}\text { Dark beer } \\
\text { (before) }\end{array}$ & $\begin{array}{c}\text { Dark beer } \\
\text { (after) }\end{array}$ \\
\hline Isoamyl acetate & banana & $87.61 \pm 0.48$ & $18.20 \pm 0.87$ \\
\hline Ethyl hexanoate & $\begin{array}{l}\text { fruity, green, } \\
\text { pineapple, sweet }\end{array}$ & $85.05 \pm 2.93$ & $14.11 \pm 0.97$ \\
\hline Ethyl octanoate & fruit, fat & $25.58 \pm 3.71$ & $12.55 \pm 0.67$ \\
\hline 3-methylbutan-1-ol & whiskey, malt, burnt & $23.53 \pm 2.82$ & $20.45 \pm 2.13$ \\
\hline 2-phenylethyl acetat & erose, honey, tobacco & $18.45 \pm 3.00$ & $17.06 \pm 1.59$ \\
\hline Phenylethylalcohol & rose & $17.61 \pm 1.33$ & $10.49 \pm 1.93$ \\
\hline Ethylacetate & fruity & $12.55 \pm 0.48$ & $5.68 \pm 0.25$ \\
\hline Octanoic acid & sweat, cheese & $5.42 \pm 0.10$ & $1.95 \pm 0.16$ \\
\hline Ethyl decanoate & grape & $2.35 \pm 0.21$ & $3.47 \pm 0.13$ \\
\hline Decanoic acid & rancid, fat & $1.73 \pm 0.34$ & $1.30 \pm 0.26$ \\
\hline Benzaldehyde & bread, almond, sweet & $1.29 \pm 0.10$ & - \\
\hline Acetic acid & sour & - & $1.00 \pm 0.07$ \\
\hline \multicolumn{2}{|c|}{ The sum of peak area: } & $281.16 \pm 19.67$ & $106.26 \pm 9.02$ \\
\hline
\end{tabular}

p-Coumaric acid, ferulic acid) and eight decrease down (epicatechin, syringic acid, vanillin, sinapic acid, 2-OHcinnamic acid, rutin, trans(3)-OHcinnamic acid, and luteolin).

\section{DISCUSSION}

Comparison of commercially available dark beer and freeze dried and rehydrated beer showed that 1) the $\mathrm{pH}$ level was almost similar, 2) mixed powdered beer with deionised water retained the original colour and extract content of commercially available dark beer.

Concentrations of volatile (aroma) compounds of dark beer were $62 \%$ lower after drying. Freeze drying is a timeconsuming process in vacuum during which time volatile compounds can be transferred from freezing beer samples to the drying chamber and then to the atmosphere. Spirit ethanol is completely lost during the process. 


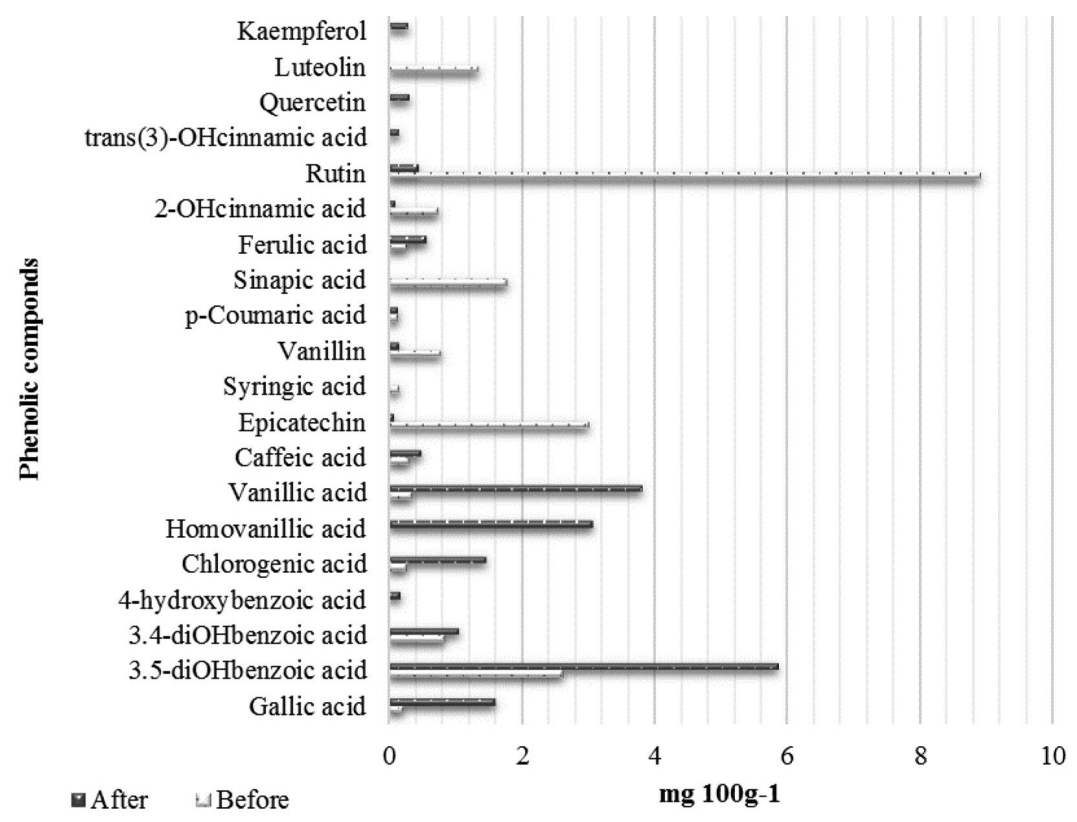

Fig. 5. Content of phenolic compounds of dark beer before and after freeze drying, $\mathrm{mg} \cdot 100 \mathrm{~g}^{-1}$.
Concentrations of most of the organic acids decreased during freeze drying process; but concentration of quinic acid slightly increased.

Among phenolic compounds, catechin had the highest concentration in dark beer samples. Concentrations of twelve of twenty phenolic compounds increased after freeze drying and decreased for eight. Unfortunately, it is not to possible to compare data obtained in the study with data in the literature as there were no scientific publications about use of freeze drying methods in beer.

\section{REFERENCES}

Cinkmanis, I. (2014). Untraditional raw materials for beer production. Doctoral dissertation. Latvia University of Agriculture, Jelgava, Latvia. 51 pp. http://1lufb.1lu.1v/dissertation-summary/Beverage_industry/ Ingmars_Cinkmanis_prom_darba_kopsavilkums_2014_LLU_PTF.

Deyse, G. P., Correa, M. L., Rocha-Leao, M. H. (2013). Production of grape juice powder obtained by freeze-drying after concentration by reverse osmosis. Braz. Arch. Biol. Technol., 56 (6). Available from:

http://www.scielo.br/scielo.php?script=sci_arttext\&pid=S1516-89132013 000600017 (last accessed 2 April 2018).

Fang, Z., Bhandari, B. (2010). Encapsulation of polyphenols: Review. Trends Food Sci. Technol., 21, 510-523.

Ghio, S., Barresi, A. A., Rovero, G. (2000). A comparison of evaporative and conventional freezing prior to freeze-drying of fruits and vegetables. Food Bioprod. Proc., 4, 187-192.

Received 8 December 2016

Accepted in the final form 16 March 2018
Hammami, C., René, F. (1997). Determination of freeze-drying process variables for strawberries. J. Food Eng., 32 (2), 133-154.

Khalloufi, S., Ratti, C. (2003). Quality deterioration of freeze-dried foods as explained by their glass transition temperature and internal structure. $J$. Food Sci., 68 (3), 892-903.

Marques, L. G., Silveira, A. M., Freire, J. T. (2006). Freeze-drying characteristics of tropical fruits. Drying Technol., 24 (4), 457-463.

Munin, A., Edwards-Levy, F. (2011). Encapsulation of natural polyphenolic compounds: Review. Pharmaceutics, 3 (4), 793-829.

Sabovics, M., Straumite, E., Galoburda, R., Kronberga, A. (2010). Analysis of volatile compounds in flour blend from non-traditional cereals in Latvia. In: Proceedings of International Conference on Food Innovation "FoodInnova 2010", Valencia, Spain, 25-29 October. Fito, P., Toldra, F. (eds.), p. 4 [CD-ROM].

Sabovics, M., Straumite, E., Ruse, K., Galoburda, R. (2013). Volatile compounds evaluation of Triticale (Triticosecale wittmack) flour blend dough in fermentation process. In: Proceedings of FaBE2013 (Food and Biosystems Engineering) International Conference, Volume II, Skiathos Island, Greece, 30 May-2 June, pp. 23-32.

Wojdylo, A., Figiel, A., Oszmianski, J. (2009). Effect of drying methods with the application of vacuum microwaves on bioactive compounds, color and antioxidant activity of strawberry fruits. J. Agricult. Food Chem., 57, 1337-1343.

Wu, R., Frei, B., Kennedy, J. A., Zhao, Y. (2010). Effects of refrigerated storage and processing technologies on the bioactive compounds and antioxidant capacities of Marion and evergreen black berries. LWT-Food Sci. Technol., 43, 5165-5170.

\section{PĒTİJUMS PAR TUMŠĀ ALUS REHIDRATĀCIJAS SALĪDZINĀŠANU PIRMS UN PĒC LIOFİLĀS ŽĀVĒŠANAS CIKLA}

Šì pētījuma mērḳis ir salīdzināt tumšo alu pirms un pēc liofilizācijas procesa. Tika noteiktas dzēriena pH, ekstraktvielu, krāsas, organisko skābju un fenola savienojumu satura izmainas. Liofilizētā tumšā alus paraugi tika analizēti, izmantojot standarta alus analīzes metodes Mitteleuropäische Brautechnische Analysenkommision (MEBAK) un divu tipu hromatogrāfijas metodes: augstas izšķirtspējas šķidruma hromatogrāfiju un gāzu hromatogrāfiju/masspektrometriju (GC/MS). Būtiskas tumšā alus pH izmaiṇas netika novērotas, salīdzinot paraugu pirms un pēc liofilizācijas. Šḳīdinot iegūto liofilizēto alus pulveri dejonizētā ūdenī, tas bija dzidrs, tumši brūns, bez nogulsnēm, kas atbilda sākotnējam komerciāli pieejamam tumšajam alum ar sākotnējo ekstrakta vielu saturu $8,88 \%$. Tika analizēts sekojošs organisko skābju sastāvs: skābeņskābe, vīnskābe, hīnskābe, ābolskābe, askorbīnskābe, pienskābe, etiksskābe, citronskābe, fumārskābe un dzintarskābe. Vienpadsmit gaistošie savienojumi ar GC/MS analīzes metodi tika izolēti no tumšā alus parauga pirms un pēc liofilizācijas. 